\title{
Analisis Sistem Operasional Hasannah Card pada PT. BNI Syariah Kantor cabang utama Bekasi
}

\author{
Ahmad Faiq \\ STAI Al-Aqidah Al-Hasyimiyyah, Jakarta, Indonesia \\ E-mail: afaiq135@gmail.com
}

\begin{abstract}
Article Info
Article History

Received: 2021-07-12

Revised: 2021-08-15

Published: 2021-09-11

Keywords:

Operating System;

Hasanah Card;

BNI Syariah..

Abstract

This study uses a descriptive qualitative approach, with the method of collecting direct observation data at the research location, namely at BNI Syariah KC Bekasi, and conducting interviews and documentation related to the Hasanah Card, then the authors make data sources based on the results of observations, interviews, documentation and facts in the field. , it was concluded and the results of this study were that the BNI Hasanah Card operational system implemented was in accordance with what was stipulated in the DSN-MUI fatwa. The contract used by the BNI Hasanah Card is in accordance with the contract ordered in the DSN-MUI fatwa, namely the kafalah, qardh, and ijarah contracts, in its implementation the Hasanah Card is in accordance with the DSN-MUI fatwa No. 54/DSN-MUI/X/2006 concerning Sharia Cards.
\end{abstract}

\begin{tabular}{ll}
\hline Artikel Info & Abstrak \\
\hline Sejarah Artikel & Penelitian ini menggunakan pendekatan kualitatif deskriptif, dengan metode \\
Diterima: 2021-07-12 & pengumpulan data observasi langsung di lokasi penelitian yaitu di BNI Syariah KC \\
Direvisi: 2021-08-15 & Bekasi, dan melakukan wawancara serta dokumentasi yang berkaitan dengan Hasanah \\
Dipublikasi: 2021-09-11 & $\begin{array}{l}\text { Card, lalu penulis menjadikan sumber data berdasarkan hasil observasi, wawancara, } \\
\text { dokumentasi serta fakta di lapangan, diperoleh kesimpulan dan hasil penelitian ini }\end{array}$ \\
Kata kunci: & adalah sistem operasional BNI Hasanah Card yang diterapkan telah sesuai dengan apa \\
Sistem Operasional; & yang detetapkan dalam fatwa DSN-MUI. Akad yang digunakan BNI Hasanah Card sudah \\
Hasanah Card; & sesuai dengan akad yang diperintahkan dalam fatwa DSN-MUI yaitu akad kafalah, \\
BNI Syariah. & qardh, dan ijarah, dalam penerapannya Hasanah Card sudah sesuai dengan fatwa DSN- \\
& MUI No.54/DSN-MUI/X/2006 tentang Syariah Card. \\
\hline
\end{tabular}

\section{PENDAHULUAN}

Indonesia sebagai negara yang mayoritas penduduknya beragama Islam terbesar di dunia juga telah merasakan kebutuhan akan adanya bank yang diharapkan dapat memberikan kemudahan-kemudahan dan jasa-jasa perbankan kepada semua umat Islam dan penduduk Indonesia yang beroperasi tanpa riba. Bank syariah merupakan lembaga keuangan yang usaha pokoknya memberikan pembiayaan dan jasa-jasa lainnya dalam lalu lintas pembayaran serta peredaran uang yang pengoprasiannya disesuaikan dengan prinsip syariat Islam, Menurut Mustofa pada penelitiannya, dapat diketahui bahwa keengganan nasabah untuk memiliki rekening dibank syariah disebabkan oleh sedikitnya fasilitas ATM yang dimilikinya. Karena banyak nasabah yang memilih untuk membuka dua rekening, yaitu bank syariah dan bank konvensional. Penggunaan rekening di bank syariah lebih diutamakan bagi simpanan jangka panjang, mislanya untuk kas Masjid, pernikahan, dan simpanan pribadi. Sedangkan rekening di bank konvensional lebih diutamakan untuk kepraktisan lalu lintas pembayaran, karena bank konvensional memiliki lebih banyak failitas dan jaringan yang memudahkan pembayaran telepon, listrik, kartu kredit, transfer, dan lain-lain.

Gaya hidup modern yang identik dengan kepraktisan dalam melakukan sebuah transaksi mendorong pihak perbankan untuk menyediakan berbagai layanan produk untuk memudahkan nasabah dalam melakukan transaksi. Tidak terkecuali dengan dikeluarkannya produk kartu kredit syariah yang tentu saja tujuannya adalah mempermudah nasabah dalam bertransaksi di merchant yang menyediakan penerimaan pembayaran dengan menggunakan kartu kredit syariah, Berdasarkan UndangUndang Nomor 10 Tahun 1998, pada tanggal 29 April 2000 telah didirikan Unit Usaha BNI Syariah (UUS) dengan 5 kantor cabang di Yogyakarta, Malang, Pekalongan, Jepara dan Banjarmasin. Sejak saat itu UUS BNI terus berkembang dan berkembang menjadi 28 Kantor Cabang dan 31 Kantor Cabang Pembantu. 
Pada Desember 2019, BNI Syariah memiliki 3 Kantor Wilayah dengan Cabang BNI Syariah yang mencapai 68 Kantor Cabang, 218 Kantor Cabang Pembantu, 13 Kantor Kas, 23 Mobil Service Motion dan 58 Payment Point, Salah satu kantor cabang BNI Syariah adalah Kantor Cabang Utama Bekasi. Kantor Cabang Bekasi adalah salah satu Kantor Cabang yang memiliki banyak sekali peminat atau nasabah, karena fasilitas yang memadai dan juga pelayanan yang memuaskan.

BNI Syariah yang bekerjasama dengan Mastercard segera me-launching kartu kredit tanpa riba yaitu Hasanah Card dengan berlandaskan fatwa DSN-MUI dan UU Perbankan yang bertujuan untuk menjadi jaminan atas transaksi dan memberikan kemudahan dalam pembayaran. Value (nilai) yang diunggulkan oleh Hasanah Card adalah bebas bunga atau riba sesuai dengan syariah, lebih ringan dari sisi biaya dan dengan fitur yang tidak kalah menarik dari kartu kredit konvensional. Selain itu, Hasanah Card pastinya memakai teknologi chip keamanan sehingga keamanan sudah terjamin, sesuai dengan permintaan pasar (nasabah) saat ini.

"Peluncuran produk Hasanah Card ini merupakan salah satu komitmen BNI Syariah untuk menyediakan produk dan layanan perbankan sesuai dengan kebutuhan masyarakat dengan gaya hidup modern yang berprinsip syariah," ujar Direktur Utama BNI, Gatot M. Suwondo dalam acara peluncuran Hasanah Card di sela acara Festival Ekonomi Syariah (FES) 2009 di Jakarta, Sabtu (7/2/2009), Dasar yang dipakai dalam penerbitan Hasanah Card adalah Fatwa Dewan Syariah Nasional (DSN) No.54/DSN-MUI/X/2006 tentang Syariah Card dan Surat Persetujuan dari Bank Indonesia No.10/337/DPbs tanggal 11-03-2008.

DSN adalah unit yang ditugaskan oleh MUI untuk menetapkan fatwa untuk produk yang akan digunakan lembaga keuangan dan melakukan kegiatan usaha sesuai prinsip syariah, Dari pertama diluncurkan, Hasanah Card sudah menimbulkan kontroversi dan keraguan oleh para penggiat bank Syariah. Para bankir masih mempertanyakan apakah Hasanah card sudah sesuai prinsip Syariah dalam penerapannya. Bahkanada yang menilai kalua Hasanah Card hamper tidak memiliki manfaat, Ada beberapa pendapat oleh para ahli tentang Syariah Card, seperti pendapat Daud Bakar (2018) "kartu kredit tidak dikenal dalam Islam, karenanya istilah yang paling tepat digunakan adalah kartu debit". Dengan kata lain, ia pada prinsipnya meragukan tingkat kesyariahan dari Syariah Card tersebut. Adapun pendapat dari Muzamil Shiddiqi "penggunaan kartu kredit sama seperti menggunakan sistem perbankan modern yang notabene berbasis riba".

Berdasarkan latar belakang di atas dan mengacu pada fatwa DSN-MUI penulis tertarik untuk meneliti lebih lanjut mengenai Sistem operasional Kartu Kredit Syariah, Hasanah Card, yang dikeluarkan oleh PT BNI Syariah. Oleh karena itu judul penelitiannya adalah "Analisis Sistem Operasional Hasanah Card pada PT BNI Syariah Kantor Cabang Utama Bekasi". Tahun 2020

\section{METODE PENELITIAN}

Dalam penelitian ini penulis menggunakan metodologi kualitatif, yang menganalisa masalah secara deskriptif tentang sistem operasional Hasanah Card pada PT. BNI Syariah kantor cabang utama Bekasi, Dengan dipilihnya metode kualitatif ini, penulis berharap dapat memperoleh data yang lengkap dan akurat. Dari perspektif sifat representasi data, penulis menggunakan pendekatan deskriptif, yaitu penelitian yang tidak mencari atau menjelaskan hubungan, dan tidak menguji hipotesis atau hasil. Selain itu, penelitian kualitatif dipilih karena metode kualitatif dapat memberikan detail yang lebih kompleks di balik fenomena yang sulit dipahami dan diketahui, sumber data yang digunakan penulis terbagi menjadi dua kategori, yaitu: Data Primer sebagai Data utama diperoleh langsung dari BNI Syariah KCU Bekasi. Untuk memperoleh data mentah tersebut peneliti melakukan observasi dan wawancara secara langsung, dan Data Sekunder yang merupakan data yang diperoleh dari dokumen grafik, foto dan objek lain yang dapat memperkaya data primer. Melalui penelitian, analisis dan telaah buku yang erat kaitannya dengan masalah yang akan diteliti, data bekas juga dapat diperoleh melalui penelitian pustaka, dan data yang dipublikasikan dengan baik dapat dipublikasikan. Dalam penelitian ini peneliti melakukan penelitian kepustakaan dengan mengunjungi beberapa perpustakaan untuk memperoleh data dari berbagai literatur, dan melakukan penelitian kepustakaan dengan mencari berbagai jenis penelitian melalui jurnal elektronik dan website resmi.

Adapun subjek penelitian ini adalah Bank BNI Syariah Kantor Cabang Utama Bekasi. Sedangkan objek penelitiannya adalah sistem operasional Hasanah Card, dan Untuk memperoleh data yang diperlukan dalam penulisan skripsi ini, peneliti 
menggunakan bebrapa teknik pengumpulan data, diantaranya adalah: 1) Penelitian Kepustakaan dan Studi Literature (Library Research and Study Literature), 2) Penelitian Lapangan (Field Research).

Analisa data dalam penelitin ini merupakan upaya bagaimana seorang peneliti dapat memilih kategori-kategori yang sesuai untuk dijadikan sebuah permasalahan sehingga dapat diorganisasikan menjadi satu kesatuan yang dapat dikelola untuk mendapatkan pemahaman yang sesuai dengan apa yang dipelajari dalam permasalahan yang diteliti untuk mengetahui sistem operasional Hasanah Card di Bank BNI Syariah KCU Bekasi. Proses analisis dimulai dengan membaca kembali semua data yang diperoleh melalui wawancara dan observasi serta dari dokumen, gambar, foto, data, dll. Selain itu ringkasan ini disusun dan dirangkum dalam unit informasi yang disiapkan untuk digunakan sebagai bahan laporan penelitian, namun telah dicek keabsahan datanya terlebih dahulu, kemudian dikembangkan dalam bentuk interpretasi data dengan melihat metode yang digunakan, karena peneliti menggunakan Metode ini merupakan metode kualitatif, sehingga peneliti mencoba mendeskripsikan sistem operasional Hasanah Card di Bank BNI Syariah KCU Bekasi. Setelah dilakukan pengujian lebih lanjut, sistem tersebut menjadi teori substantif dan menjadi inti penelitian.

\section{HASIL DAN PEMBAHASAN}

\section{A. Kartu Kredit Syariah}

Salah satu produk hasil ijtihad Dewan Syariah Nasional - Majelis Ulama Indonesia (DSN-MUI) adalah Syariah Card, yaitu sejenis kartu yang berfungsi seperti kartu kredit namun berdasarkan prinsip syariah. Masyarakat Indonesia umumnya menyebut Syariah Card ini sebagai Kartu Kredit Syariah, Pada dasarnya kata kartu kredit kurang cocok disematkan pada Hasanah Card, karena kata kredit identik dengan bunga, oleh karena itu pihak BNI Syariah sendiri menyebut Hasanah Card dengan sebutan kartu pembiayaan, tapi berhubung masyarakat sudah familiar dengan kata kredit oleh karena itu BNI Syariah menyesuaikan dengan pemahaman masyarakat, dan sekarang masyarakat mengenal Hasanah Card dengan Kartu Kredit berbasis Syariah.

Secara harfiah kartu kredit tetap tidak bisa berprinsip syariah, karena kredit adalah pinjaman dan cicilan, jadi Hasanah Card adalah kartu pembiayaan yang berbasis syariah yang fungsinya hampir sama dengan kartu kredit. Hal ini sebagaimana dikemukakan oleh A. Dobig Mirandi sebagai Bussines Manager BNI Syariah Kantor Cabang Bekasi sebagai berikut:

"Kalau berbicara kartu kredit, sebenarnya kita menyebut Hasanah card adalah kartu pembiayaan, pembiayaan adalah segala sesuatu yang kita akan segera bayar atau sistem pembayaran, jadi bukan kredit, kalau kredit lain lagi nantinya, sekali lagi yang kita sampaikan adalah yang ma'fum di khalayak ramai, kalau kita menyebutnya kartu pembiayaan orang pasti akan bertanya-tanya apa maksudnya?, maka pada akhirnya kita menyebutnya dengan kartu kredit berbasis syariah, nah kalau secara harfiah, ga bisa kartu kredit sesuai syariah, artinya tetap saja minjem dan nyicil, nah, kalau ini kartu pembiayaan yang berbasis syariah, yang fungsinya seperti kartu kredit baru cocok, jadi bukan kartu kredit yang syariah tapi kartu pembiayaan yang fungsinya seperti kartu kredit konvensioal kebanyakan di masyarakat."

\section{B. Keunggulan Hasanah Card Dengan}

Aturan mengenai Syariah Card ini diatur dalam fatwa DSN-MUI No 54 tahun 2006. DSN MUI menilai Syariah Card mengandung maslahah karena masih dibutuhkan masyarakat. Adapun semangat yang diusung adalah menghadirkan solusi kartu pembiayaan tanpa riba dan menghilangkan tendensi konsumtif (QS. Al-Furqon: 67). Cara yang digunakan untuk menghilangkan tendensi konsumtif dengan memberi limit pembiayaan dan tidak mengadakan promopromo berlebih, serta BNI Hasanah Card tidak akan bisa digunakan di tempat atau Merchant yang tidak halal, seperti Bar, Diskotik, dan lain sebagainya walaupun hanya sekedar membeli air mineral tidak akan bisa digunakan. Hal ini sebagaimana dikemukakan oleh Asteria Ekawati sebagai Funding Assistant BNI Syariah Kantor Cabang Bekasi sebagai berikut:

"Kalau kita transaksi di merchant yang Non Halal kita otomatis tertolak, beli minuman keras, ke Diskotik sudah pasti tertolak."

Dalam kaidah fiqih pun disebutkan bahwa "Hukum asal bermuamalah adalah boleh, sampai ada dalil yang mengharamkannya." Karena itulah Bank Syariah memiliki produk yang sangat dinamis, yang mengikuti 
kebutuhan muamalah masyarakat, namun tetap sesuai prinsip dan nilai Syariah.

Hasanah Card tidak mengambil keuntungan dari penundaan pembayaran, melainkan dari jasa atas kemudahan transaksi yang diberi oleh Bank Syariah. Sesuai fatwa DSNMUI, Syariah Card yang sesuai dengan prinsip Syariah, dalam Syariah Card, ujroh atau fee tidak dihitung berdasarkan jumlah hari penundaan pembayaran. Adapun terkait denda keterlambatan dan biaya ganti rugi, Bank Syariah penerbit kartu dibolehkan untuk mengenakan late charge pembayaran yang akan diakui seluruhnya sebagai dana sosial. Dan penerbit juga dapat mengenakan ganti rugi terhadap biaya-biaya yang dikeluarkan oleh penerbit akibat keterlambatan pemegang kartu dalam membayar kewajibannya yang telah jatuh tempo. Hal ini sebagaimana dikemukakan oleh A. Dobig Mirandi sebagai Bussines Manager BNI Syariah Kantor Cabang Bekasi sebagai berikut:

"Sesuai fatwa DSN-MUI Syariah Card yang sesuai dengan prinsip Syariah harus memenuhi tiga kriteria: Tidak mengenakan bunga, tidak mengenakan fee penjaminan Bank atas kewajiban nasabah terhadap merchant, membership fee dan mengenakan donasi sosial atau ganti rugi atas setiap keterlambatan pembayaran karena kita tanpa denda, Syariah card tidak digunakan untuk transaksi yang bertentangan dengan Syariah, tidak mendorong pengeluaran yang berlebihan".

BNI Syariah dengan produk Hasanah Card senantiasa mengikuti prinsip Syariah sebagaimana telah difatwakan oleh DSN-MUI.

\section{Pro dan Kontra Hasanah Card}

Sejak awal diterbitkannya, Syariah Card memang menimbulkan banyak keraguan dan kontroversi para pelaku perbankan syariah. Para bankir masih meragukan apakah Syariah Card sesuai dengan prinsip-prinsip syariah yang ada dalam transaksi syariah. Lebih dari itu, sebagian pelaku bisnis bank syariah menilai bahwa dari segi manfaat Syariah Card sangat kecil sekali, beberapa pendapat tentang Syariah Card ini antara oleh Daud Bakar (2018) dan Muzammil Shiddiqi (2016). Daud Bakar mengutarakan bahwa kartu kredit tidak dikenal dalam Islam, karenanya istilah yang paling tepat digunakan adalah kartu debit. Dengan kata lain, ia pada prinsipnya meragukan tingkat kesyariahan dari Syariah Card tersebut. Adapun Muzammil Shiddiqi berpendapat bahwa penggunaan kartu kredit sama seperti menggunakan sistem perbankan modern yang notabene berbasis riba.

Dalam negara demokrasi kita tidak bisa menyalahkan pendapat orang lain, karena setiap orang memiliki pendapat yang berbeda beda, akan tetapi sebelum memberikan pendapat alangkah baiknya untuk meneliti atau mengetahui dahulu apa yang ingin dinilai, jangan menilai sesuatu hanya dari satu sudut pandang atau satu sumber saja. Hal ini sebagaimana dikemukakan oleh Asteria Ekawati sebagai Funding Assistant BNI Syariah Kantor Cabang Bekasi sebagai berikut:

"Kita engga bisa menyalahkan pendapat orang lain ya, karena kita hidup di negara demokrasi, tapi, kalo pendapat saya, kartu kredit tergantung dari penggunaannya, kalo misalkan digunakan secara berlebihan itu tidak disarankan, dan memang tidak dianjurkan untuk ngutang dalam islam, jadi pendapat itu kembali ke dirinya masing masing, bagaimana dia menggunakan kartu kredit itu, tapi jika digunakannya baik dan digunakan dengan wajar itu tidak masalah kok."

Pendapat yang diberikan oleh Daud Bakar (2018) dan Muzammil Shiddiqi (2016), hanya dari satu sudut pandang, karena mereka hanya membaca teknisnya saja, sedangkan belum mengetahui operasional dan penerapannya, Begitupun masih banyak konsumen yang berpendapat bahwa Hasanah Card tidak sesuai, karena preteks mereka tentang "Kredit" itu pasti riba tanpa mereka tahu bagaimana operasional, akad dan penerapannya, padahal Hasanah Card sendiri bukanlah Kartu Kredit tapi kartu pembiayaan sesuai yang telah dipaparkan diatas, hanya saja BNI Syariah menggunakan kata yang telah umum dipakai di masyarakat. Hasanah Card adalah kartu pembiayaan yang fungsinya hampir sama dengan kartu Kredit. Hal ini sebagai mana dikemukakan oleh Fanny Ardian sebagai Salles Head BNI Syariah Kantor Cabang Bekasi:

"Sebenarnya kalau pro dan kontra ini lebih ke konsumennya sih, mereka masih berfikir kalau itu sama saja dengan bank konvensional, ada juga orang yang memang alergi dengan kartu kredit, jadi yaudah mau itu regular atau syariah pokoknya dia gak mau." 
Jika memang benar ada yang tidak sesuai Syariah sebaiknya berdiskusi dengan pihak bank BNI Syariah dan memperbaiki bersama apa yang harus diperbaiki, seharusnya jika berpendapat demikian mereka juga harus memberi solusi yang sesuai, agar pendapat mereka diterima sebagai kritik ataupun saran, oleh karena itu pendapat mereka tidak solitif dan cenderung propokatif. Hal ini sebagaimana dikemukakan oleh A. Dobig Mirandi sebagai Bussines Manager BNI Syariah Kantor Cabang Bekasi sebagai berikut:

"Pernahkah mereka duduk bareng dengan kita, pastinya belum pernah, apalagi mereka merasa tinggi karena lulusan Madinah atau Kairo, ini adalah sifat dasar manusia dan wajar menurut saya, manusiawi, bahwa saya lulusan syariah dari luar negri, tapi pada dasarnya taukah dia apa itu Hasanah Card?, dan taukah dia perjuangan Bank Syariah di Indonesia, pasti tidak tahu, harusnya saat dia ada statement, dia ada solusi dan cara yang benarnya, tapi yang sesuai dengan negara kita seperti OJK dan DSN, harusnya mereka seperti itu, makanya tidak solutif dan cenderung propokatif.

Selain nama-nama diatas ada nama yang lebih terkenal yaitu Dr. Erwandi Tarmizi, Lc. MA, seorang pakar muamalat kontemporer yang menjadi lulusan terbaik di Universitas Al-Imam Muhammad bin Saud Madinah di jurusan Ekonomi Syariah, beliau bisa menerima Hasanah Card bahkan sudah berdiskusi mengenai Hasanah Card dengan pihak BNI Syariah. Oleh karena itu Ustad Erwandi mengajak komunitas-komunitas yang tadinya anti dengan Bank Syariah menjadi bisa menerima Bank Syariah terutama BNI Syariah. Hal ini sebagaimana dikemukakan oleh A. Dobig Mirandi sebagai Bussines Manager BNI Syariah Kantor Cabang Bekasi sebagai berikut:

"Karena selain nama diatas ada nama yang tidak kalah bagusnya adalah Ustad Erwandi, lulusan Madinah, terbaik Ekonomi Syariah, itu bisa menerima dan duduk bareng dengan BNI Syariah dan menciptakan komunitaskomunitas, yang kemari komunitas itu tidak mau ke Bank Syariah, tapi sekarang sudah berubah menjadi sangat terbuka dengan Bank Syariah, terutama BNI Syariah."

Hasanah Card diterbitkan sesuai ketentuan DSN-MUI No.54/DSN-MUI/X/2006, jadi jika ada yang menentang prinsip Hasanah Card bisa dibilang mereka juga menentang fatwa
DSN MUI, karena Hasanah Card terbit berdasarkan fatwa DSN MUI, oleh karena itu sebaiknya berprasangka baik dulu, lalu berdiskusi mengenai Hasanah Card jika ada yang dirasa kurang sesuai agar tidak memprovokasi masyarakat dengan Statement yang belum tentu benar, karena itu hanya memberikan kesan buruk dan tidak percaya dengan Bank Syariah, seluruh Nasabah pengguna Hasanah Card juga setuju bahwasannya Hasanah Card sudah sesuai dengan prinsip Syariah dan setelah menggunakannya mereka tidak menemukan ada yang tidak sesuai dalam penerapanny, menurut Fiqri Syurikha seorang nasabah pengguna Hasanah Card:

"Insyaallah saya setuju bahwa Hasanah Card sudah sesuai dengan prinsip Syariah."

Menurut Delonika Dyah Ayu seorang nasabah pengguna Hasanah Card:

"Hasanah Card sudah sesuai dengan Syariah."

Menurut Dini Prima Suci seorang nasabah pengguna hasanah Card:

"Saya setuju Hasanah Card sudah sesuai prinsip syariah dan tidak ada yang melenceng dari ajaran agama."

\section{Sistem Operasional Hasanah Card yang Diterapkan Pada Bank BNI Syariah KCU Bekasi}

Sebagai salah satu produk BNI Syariah, Hasanah Card sudah pasti memiliki Standar Operasional Produk (SOP), yang menjadi landasan operasional Hasanah Card, dalam penerapannya Hasanah Card sudah sangat sesuai dengan SOP yang berlaku dan Hasanah Card sudah menggunakan Sistem dalam penerapannya sehingga mengurangi resiko Human Eror dalam penerapannya. Hal ini sebagaimana dikemukakan oleh A. Dobig Mirandi sebagai Bussines Manager BNI Syariah Kantor Cabang Bekasi sebagai berikut:

"SOP Hasanah Card pastinya tentu ada, karena untuk timbul dan lahir dan menjadi produk dan transaksi itu harus memenuhi kriteria yang diyaratkan oleh OJK dan DSNMUI, yang jelas sebelum Hasanah Card di launching SOP-nya sudah kita buat sedemikian rupa. Dan dalam prakteknya berbeda dengan Murabahah sehingga dia tidak begitu ribet karena dia sudah By Sistem jadi tidak ada campur tangan kita sehingga menghindari Humman Eror. 
Manajemen produk dan Sistem Operasional Produk sudah diatur oleh divisi Card Bussines Development (CBD), divisi ini yang mengatur tentang produk, kerja sama promo dan manajemen kartu. Hal ini sebagai mana dikemukakan oleh Fanny Ardian sebagai Salles Head BNI Syariah Kantor Cabang Bekasi:

"Untuk Manajemen Produk dan SOP Hasanh Card kita ada, karena kita punya divisinya sendiri, divisinya namanya (CBD) Card Bussines Development, itu semua yang mengurus tentang produk, kerjasama promo itu adanya disana".

Selain itu Hasanah Card sudah lulus uji keSyariahan oleh DSN-MUI dan Dewan Pengawas Syariah (DPS) Bank BNI Syariah, dan dalam penerapannya Hasanah Card terus diawasi oleh DPS dan Otoritas Jasa Keuangan (OJK), jadi operasional Hasanah Card sudah sangat sesuai dengan SOP dan fatwa DSN-MUI. Hal ini sebagaimana dikemukakan oleh A. Dobig Mirandi sebagai Bussines Manager BNI Syariah Kantor Cabang Bekasi sebagai berikut:

"Perbankan itu ada yang memayunginya, kalo konvensional hanya dibawah BI atau OJK yang mengontrolnya. Kalau Bank Syariah ada dua yaitu OJK dan (DSN) Dewan Syariah Nasional, yang didalam dewan pengawas Syariah, masing masing mereka punya tim DSN sendiri, berdasarkan dua itu kemudian munculah fatwa MUI tentang Syariah Card. Dalam Fatwa MUI nya itu dia sudah dianalisa secara rasionalnya dan secara Syariahnya dan itu kredibel dan kompeten, jadi kita tidak bisa seenaknya mengeluarkan dan bertranaksi. Berdasaran itu harusnya Hasanah Card sudah sesuai, karena sudah ada fatwa MUI nya berdasarkan fatwa DSNMUI No.54/DSN-MUI/X/2006.

Menurut Dini Prima Suci seorang nasabah pengguna hasanah Card:

"Syaratnya cukup ngelampirin KTP, NPWP, kemudian slip gaji terakhir kurang lebihnya begitu, lalu nanti kantor tempat saya bekerja ditelfon untuk verifikasi gaji saya."

Sebagai kartu kredit Syariah Hasanah Card tentu memiliki batasan batasan penggunaan yang bertujuan untuk tidak mendorong pengeluaran berlebih dan tidak menggunakan untuk membeli sesuatu yang tidak Syar'i.

Hal ini sebagaimana dikemukakan oleh A. Dobig Mirandi sebagai Bussines Manager BNI
Syariah Kantor Cabang Bekasi sebagai berikut:

"Hasanah Card pastinya terhindar dari riba, karena kita memagarinya dengan tiga akad tadi, sehingga apapun transaksi kita sudah dipagari dengan tiga akad tadi, selanjutnya, Hasanah Card tidak bisa dipakai untuk transaksi yang tidak Syariah, tidak mendorong pengeluaran berlebih, tetapi dalam hal ini nasabah pengguna harus disiplin dalam menggunakannya, karena pasti ada aja celah di masyarakat, dan yang terakhir diawal akad, calon nasabah dipastikan harus memiliki kemampuan finansial untuk melunasi pada waktunya."

Keunggulan lainnya, jika dibandingkan dengan Bank Umum Syariah yang lain jelas BNI Syariah paling unggul karena Hasanah Card adalah kartu kredit Syariah pertama dan satu satunya hingga saat ini yang dikeluarkan Bank Umum Syariah (BUS), dalam pengelolaan dan pengoperasionalan Hasanah Card, sudah menggunakan Sistem yang disebut ICON, jadi pengoperasionalan Hasanah Card sudah disesuaikan dengan akad dan fatwa DSN-MUI sehingga meminimalisir terjadinya Human Eror. Jadi dari sisi operasional Hasanah Card sudah sangat sesuai dengan ketentuan DSN-MUI dan OJK.

\section{E. Akad yang Terdapat Dalam Hasanah Card}

Sesuai fatwa DSN-MUI No.54/DSNMUI/X/2006, ketentuan akad yang dipakai Syariah Card adalah sebagai berikut: Ketentuan Akad Syariah Card DSN-MUI No.54/DSN-MUI/X/2006, diantaranya: a) Kafalah; dalam hal ini Penerbit Kartu adalah penjamin (kafil) bagi Pemegang Kartu terhadap Merchant atas semua kewajiban bayar (dayn) yang timbul dari transaksi antara Pemegang Kartu dengan Merchant, dan/atau penarikan tunai dari selain bank atau ATM bank Penerbit Kartu. Atas pemberian Kafalah, penerbit kartu dapat menerima fee (ujrah kafalah), b) Qardh; dalam hal ini Penerbit Kartu adalah pemberi pinjaman (muqridh) kepada Pemegang Kartu (muqtaridh) melalui penarikan tunai dari bank atau ATM bank Penerbit Kartu, 3) Ijarah; dalam hal ini Penerbit Kartu adalah penyedia jasa sistem pembayaran dan pelayanan terhadap Pemegang Kartu. Atas Ijarah ini, Pemegang Kartu dikenakan membership fee.

Dari akad Kafalah, bank menjadi penjamin bagi nasabah atas transaksi yang 
dilakukannya di pihak merchant atau pedagang (QS Yusuf ayat 72). Jaminan tersebut diberikan oleh bank atas transaksi yang dilakukan nasabah dengan menggunakan Hasanah Card sehingga bank berhak atas Ujroh atau biaya jasa (fee). Hal ini sebagai mana dikemukakan oleh Fanny Ardian sebagai Salles Head BNI Syariah Kantor Cabang Bekasi:

"Kalo akad kafalah ini kita selaku Bank, menjadi penjamin atas pembayaran yang dilakukan oleh nasabah pengguna Hasanah Card, jadi istilahnya pembayaran si nasabah ini kita yang menalangi dulu."

Sedangkan Akad Ijarah yaitu: BNI Syariah adalah penyedia jasa sistem pembayaran dan pelayanan terhadap pemegang BNI Hasanah Card. Atas Ijarah ini, pemegang BNI Hasanah Card dikenakan annual membership dan mounthly membership fee. Hal ini sebagaimana dikemukakan oleh A. Dobig Mirandi sebagai Bussines Manager BNI Syariah Kantor Cabang Bekasi sebagai berikut:

"Akad kita ada tiga, jadi Hasanah Card itu sudah memagari Penggunanya untuk terhindar dari riba dan terjerat hutang ataupun barang haram, akadnya ada Kafalah, Qardh dan Ijarah, Kafalah adalah, Bank mewakilkan dirinya untuk pengguna bertransaksi di merchant-merchant. Akad Qardh adalah talangan,Bank mewakili pemegang Hasanah Card untuk menalangi dia mengambil tunai di ATM. Akad Ijarah adalah BNI Syariah sebagai penyedia sistem pembayaran kepada nasabah pengguna Hasanah Card."

Artinya akad yang terdapat pada Hasanah Card sudah sesuai dengan fatwa DSN-MUI No.54/DSN-MUI/X/2006 tentang Syariah Card.

\section{F. Kesesuaian Hasanah Card Terhadap Fatwa DSN MUI No.54/DSN-MUI/X/2006}

Kesesuaian Hasanah Card dengan Fatwa DSN-MUI dapat dinilai dari beberapa aspek, diantaranya: 1) Iuran Keanggotaan (Membership Fee), 2) Fee Kafalah, 3) Fee Penarikan Uang Tunai, 4) Ta'widh, 5) Transaksi, dan 6) Israf.

\section{G. Kritik dan Saran untuk Hasanah Card}

Terlepas dari operasional Hasanah Card, beberapa nasabah pengguna Hasanah Card yang penulis wawancarai hampir semua sepakat bahwasannya Hasanah Card kekurangan satu hal, yaitu promo, para nasabah menginginkan promo untuk Hasanah Card ditambah lagi agar dapat bersaing dengan kartu kredit konvensional, karena jika ada promo yang mendukung nasabah pun akan senang menggunakan Hasanah Card.

Namun semua kritik dan saran itu dijawab oleh Bussines Manager BNI Syariah Bekasi, Hasanah Card memang sidikit sekali promo, karena itu agar nasabah pengguna Hasanah Card tidak konsumtif menggunakan Hasanah Card, karena hal itu dilarang dalam agama kita, dan juga dilarang dalan fatwa DSN-MUI. Hasanah Card mengadakan beberapa promo seperti tiket pesawat dan penginapan hanya untuk perjalanan bisnis, karena itu merupakan kebutuhan dan Hasanah Card memfasilitasi itu.

\section{SIMPULAN DAN SARAN}

\section{A. Simpulan}

Dalam penerapannya Hasanah Card sudah sesuai dengan fatwa DSN-MUI No.54/DSNMUI/X/2006 tentang Syariah Card. Dewan Syariah Nasional Majelis Ulama Indonesia (DSNMUI) telah membolehkan Syariah Card dan mekaniske Syariah Card sudah diatur dalam fatwa NO:54/DSN-MUI/X/2006 tentang Syariah Card. Hanya saja Fatwa yang dibuat DSN-MUI terlalu umum dan luas. Perlu adanya pernyataan atau tinjauan khusus dari DSN-MUI yang menjelaskan dan menjabarkan setiap detil dan ketentuan-ketentuan fatwa yang akan dijadikan pedoman bagi Bank Syariah. Bank BNI Syariah umumnya sudah menjalankan operasional Hasanah Card sesuai dengan fatwa DSN-MUI No.54/DSN-MUI/X/2006 tentang Syariah Card. Pihak BNI Syariah pun didampingi oleh Dewan Pengawas Syariah (DPS) sudah mengupayakan bahwa segala ketentuan-ketentuan dalan operasional Hasanah Card tidak menyimpang atau bertentangan dengan fatwa DSN-MUI No.54/DSN-MUI/X/2006 tentang Syariah Card. Operasional iB Hasanah Card sudah sesuai dengan fatwa NO:54/DSN-MUI/X/2006 tentang Syariah Card. Adanya kartu kredit syariah menjadi sebuah pilihan yang tepat bagi umat muslim di indonesia khususnya dan di dunia umumnya dibanding dengan menggunakan kartu kredit konvensional yang jelas terdapat riba di dalamnya.

\section{B. Saran}

Adapun saran yang dapat disampaikan berdasarkan pada hasil penelitian ini, yaitu: 
a) BNI Syariah harus lebih mensosialisasikan keberadaan Hasanah Card kepada masyarakat luas dan Hasanah Card harus bekerjasama dengan merchant-merchant ataupun pihak-pihak tertentu agar penggunaan Hasanah Card lebih efisien, dan perlu adanya pengawasan dalam sistem Hasanah Card guna menghindari Gharar (ketidakjelasan).

b) Hasanah Card adalah kartu kredit Syariah pertama dan satu satunya di Indonesia, oleh karena itu alangkah baiknya BNI Syariah melakukan tinjauan ulang mengenai akad dan operasional Hasanah Card bersama pihak DSN-MUI dan ulama agar tidak ada lagi keraguan dalam Hasanah Card.

\section{DAFTAR RUJUKAN}

Al-Qur'an dan Al Hadist.

Arikunto, Suharsimi. 2010. Prosedur Penelitian: Suatu Pendekatan Praktik. Jakarta: Rineka Cipta.

Ascarya. 2007. Akad \& Produk Bank Syariah. Jakarta: PT RajaGrafindo Persada.

BNI Syariah. (2020). Kartu Ib Hasanah. 10 Agustus 2020.

Bungin, Burhan. 2013. Metodologi Penelitian Sosial dan Ekonomi. Jakarta: Kencana Prenamedia Group.

Darmawi, Herman. 2006. Pasar Finansial dan Lembaga-lembaga Finansial. Jakarta: PT Bumi Aksara.

Dewi, Gemala. 2007. Aspek-aspek Hukum dalam Perbankan dan Perasuransian Syariah di Indonesia. Edisi Revisi, Cet. Ke-4. Jakarta: Kencana.

Hakim, Atang. 2011. Fiqih Perbankan Syariah: Transformasi Fiqih Muamalah ke dalam Peraturan Perundang-undangan. Bandung: PT Refika Aditama.

Hamidin, Aep S. 2010. Tips \& Trik Kartu Kredit: Memaksimalkan Manfaat dan Mengelola Risiko Kartu Kredit. Yogyakarta: Media Pressindo.

Hermansyah. 2008. Hukum Perbankan Nasional Indonesia. Edisi Revisi, Cet. Ke4. Jakarta: Kencana.
Huda, Nurul, Mohamad Heykal. 2010. Lembaga Keuangan Islam: Tinjauan Teoretis dan Praktis. Edisi Pertama, Cet. Ke-1. Jakarta: Kencana.

Ibrahim, Johannes. 2004. Kartu Kredit: Dilematis Antara Kontrak dan Kejahatan. Bandung: PT Refika Aditama.

Moelang, Lexi J. 2000. Metodologi Kualitatif. Bandung: PT. Remaja Rosdakarya.

Muhammad. 2005. Sistem Bank Syariah. Yogyakarta: UPP AMP YKPN.

Mustofa. 2005. Tinjauan Hukum Islam terhadap Deposito Perbankan. Vol.02, hlm. 269. ejournal.iain-tulungagung.ac.id (diakses Agustus 2020).

Rahmat, Jalalidin. 2000. Metodologi Penelitian Komunikasi. Bandung: PT. Remaja Rosdakarya.

Saliman, Abdul Rasyid, et al. 2008. Hukum Bisnis untuk Perusahaan: Teori dan Contoh Kasus. Edisi Kedua, Cet. Ke-4. Jakarta: Kencana.

Sholihin, Ahmad Ifham. 2010. Buku Pintar Ekonomi Syariah. 16 September 2020

Soemitra, Andri. 2010. Bank dan Lembaga Keuangan Syariah. Edisi 1, Cet. Ke-2. Jakarta: Kencana.

Staurus, Anslem. Corbin, Juliet. 2007. Dasardasar Penelitian Kualitatif. Surabaya: PT. Bina Ilmu Offset.

Sunaryo. 2009. Hukum Lembaga Pembiayaan. Edisi 1, Cet. Ke-2. Jakarta: Sinar Grafika.

Usman, Husaini. Akbar, Purnomo Setiady. 2011. Metodologi Penelitian Sosial. Jakarta: Bumi Aksara.

Wardani, Fitri Anis. 2016. Kartu Kredit Syariah dalam Tinjauan Islam. Vol 1, hlm 33. ejournal.alqolam.ac.id (diakses Agustus 2020).

Wibowo, Edy. Widodo, Untung Hendy. 2005. Mengapa Memilih Bank Syariah?. Jakarta: Ghalia. 